\title{
Tracing the origins of verlan in an early 19th century text? ${ }^{1}$
}

\begin{abstract}
This paper examines early attestations of verlan and related backward slangs in French in the 19th century. Its main contribution is the edition and analysis of the only known text, a letter, written with features of verlan before the $20^{\text {th }}$ century. This largely predates other attested forms of verlan. The principles underlying this early form of verlan are shown to be different from contemporary verlan, as is much other early evidence, though all forms have the syllable as their basic unit. The letter is evidence that backward slangs can originate in the education system as much as in the underworld of thieves.
\end{abstract}

Key words: verlan; Occitan; metathesis; slang; historical linguistics

\section{Introduction}

Verlan is a French-based code, a type of backward slang, which has been in use in the banlieues and urban lower classes of French society for the past sixty years or so. A characteristic of backward slang is the widespread use of metathesis in the coding of words, together with other processes such as

\footnotetext{
$1 \quad$ This research was conducted during a Laming Junior Fellowship at The Queen's College, Oxford. My thanks go to Brigitte Benneteu, Conservatrice départementale des Musées du Tarn, and her team, for allowing access to archives at the Château du Cayla, and for granting permission to publish Boubée's letter. I express my gratitude to Louise Esher, Martin Maiden and Pierre-Joan Bernard for comments on earlier versions of this paper, as well as three anonymous reviewers whose constructive comments have greatly improved the quality of this work. Any shortcomings are obviously mine.
} 
truncation and resyllabification. Other languages in the world have given rise to various forms of backward slang, such as backslang in England or various urban metathetic slangs in Indonesia (see examples in KirshenblattGimblett, 1976; Vázquez Ríos, 2009). What makes French verlan so distinctive is the fact that a large number of verlanised words have been lexicalised as part of normal, everyday speech, as well as the extent to which verlan is or has been used by diverse groups, mostly among young people. Many studies have described and analysed the modern forms of verlan (Bachmann and Basier, 1984; Lefkowitz, 1991; Plénat, 1992, 1995; Méla, 1988, 1991, 1997 among others). Some studies analyse verlan in order to deduce more general principles applicable to the phonological structure of French (Lefkowitz, 1989; Lefkowitz and Weinberger, 1991; Azra and Cheneau, 1994; Plénat, 1995; Walker, 2006). Another group of studies considers the usage of verlanised forms in discourse and the various social settings and contexts of use of verlan (Bachmann and Basier, 1984; Méla, 1991, 1997; Antoine, 1998). Modern verlan forms exclusively target content words, including monosyllables; they roughly reverse the order of syllables, often by treating monosyllables as disyllabic; and they are affected by various processes of truncation ${ }^{2}$.

What is much less well known is the diachronic development of this

For reasons of space, it is not possible here to present more precisely the formation of words in modern verlan (clearly set out in a number of theoretical frameworks by Azra and Cheneau, 1994; Lefkowitz, 1991; Lefkowitz and Weinberger, 1991; Plénat 1992, 1995 amongst others). 
form of slang, and in particular how far back it can be attested. Although the term verlan is a relatively recent coinage (c. 1950, see Lefkowitz, 1991:52), there are anecdotal attestations of verlanised forms in the $19^{\text {th }}$ century (see Lefkowitz, 1991:50-52 for a summary). Only a few isolated forms are attested, possibly because it is rare to write an entire text in slang. As will be shown, most of the historical evidence for verlan prior to the Second World War in fact illustrates forms of largonji, and the few real occurrences are isolated forms which do not provide information about their context of use (see section 4.2). This paper presents archival and historical evidence for the use of backward slang forms in French in the early $19^{\text {th }}$ century. A number of codes using segment displacement or replacement, sometimes with the adjunction of various suffixes or with truncation, are attested in France in the $19^{\text {th }}$ century. Largonji or largonji des loucherbems essentially consists in replacing the initial consonant of the word by l- and adding the initial consonant at the end of the word followed by various suffixes (see Plénat, 1985), as in the form largonji from jargon. Javanais is another argotic code where an infix -av- is added in between syllables, or after the first consonantic element (see Bullock, 1996; Plénat, 1991).

Verlan is generally believed to be first attested as a generalisation of a word game into a form of slang in the milieu of prisoners and convicts (Lefkowitz, 1991:53), although the word verlan itself is only attested in 1953 and the phenomenon gains wider usage only in the second half of the 
$20^{\text {th }}$ century. Evidence for use of such a form of backward slang in the $19^{\text {th }}$ century is scarce, and the first attestations of its use consist of a few isolated forms around 1840. The earliest attestations are believed to be linspré for le prince 'the prince' in Vidocq (1837) and Lontou for Toulon, from the name given in a letter by a convict, La Hyène, dated 1842 (Sers, 1842:53; see also Sainéan, 1912).

The document edited here is, to my knowledge, the first attested text written with features of verlan, and precedes known attestations of largonji and most early verlanised forms. It is a letter written by Benjamin Boubée, a 13-year-old student at the Catholic Seminary in Toulouse, to his friend Maurice de Guérin, later known as a writer and one of the first authors to experiment with prose poems in French literature (D'Harcourt 1932; Vest, 1992). The letter is dated 10 October 1823, and comprises two parts, one written in Occitan, the regional language spoken in southern France, the other in a verlanised version of French ${ }^{3}$. This text using a French backward slang was not in the milieu of prisoners and convicts, but in a respectable school for gentry: the Petit Séminaire de l'Esquile was one of the best schools in Toulouse. But while other schools, the colleges and the

$3 \quad$ The letter is mentioned by Decahors (1932:57) in his biographical study of Maurice de Guérin. He only publishes the first sentence of the verlanised part. I first came across this document while making a survey of the Occitan texts conserved in the Musée du Cayla. The archive mainly consists of texts, correspondence and documents relating to Maurice de Guérin and his sister Eugénie, both of whom were writers, and to their family. This letter is the only letter conserved from Maurice's childhood that was not sent by his family. It is likely that it was conserved purely by chance. Similar documents are bound to be extremely rare, because such codes are rarely written. Historical sources for French slangs prior to the $19^{\text {th }}$ century can mostly be found in court case files, a kind of documentation that skews historical investigations towards the criminal milieu. 
University tended to the liberal side, and were frequently involved in political debate and riots, the Petit Séminaire was a Catholic, conservative, and morally rigorous school (Decahors, 1932:52-54). Students had the status of reverends (French 'abbé'), and wore ecclesiastical attire. The local gentry who supported the royalist party and the Bourbon Monarchy all had their sons attend this school, which numbered around 500 students in 1817. Latin language and Roman antiquity, in addition to religion, formed the core of studies, and a sizeable number of students became priests (Decahors, 1932:54-55). At the date of the letter, Maurice de Guérin had attended the school for a year and a half.

The structure of this paper is as follows. I first provide a critical edition of the letter, and a translation of it. In the second part, I provide a full glossary of verlanised forms, with their non-verlanised equivalents, all grouped according to the rules used in the transformation and the phonological shape of words. The analysis that follows examines the phonetic interpretation of the verlanised words and the question of whether this code might have been used in a spoken form, as well as its relationship with other early attestations of metathetic slangs and modern verlan. I finally conclude the paper with a reappraisal of the evidence for an early formation of verlan.

\section{Critical edition of the text}


The letter is here transcribed as in the original manuscript. Deletions are indicated by strikethrough. Words that had to be restablished are indicated between square brackets. The translation provided following this edition should be understood as a free translation whose only aim is to give a sense of the content of the letter. The precise question of forms, and translation thereof, is addressed in the next section.

\subsection{Critical edition of the letter}

Letter by Benjamin Boubée to Maurice de Guérin, 11.X.1823, 2fol., 20x12cm. Andillac, Archives du Château du Cayla, AG471.

Toulouse ce 11 octobre 1823

La Mÿou catêto,

Ÿeou, catêto, t'abioi proumetut, catêto, de t'escriouré; beses bé que aou fauc. Mais ma catêto, t'abioi proumetut tabes de fa la letro en bermino latino, à counditiou, saquela Catêto, què me respoundrios dammè la mêmo bermino. Mais la mÿou catétasso, t'es bé tu mêmo apercebut qué pendent las bacansos l'on n'a pas gairé embéjétos de fa de bermino. disi pas saquèla aquos de tu, ma cateto, persoque aprep coucou es le pus balent siugè. Ainsi dounc, ma catêto tè prègi dé bouler pla récébré, (escouto pla catêto) ma letro sans bermino.

Ço qu'ai dit dunquos aci n'es pas qu'uno ferbento pregairo et un 
perdou que t'adresso le tÿou coucou dammè pla dè soumissiou et de respect.

Ami mon cher à moi

Il ÿ a \& jéda longtemps que je séridais t'ericre pour te medander de tes vounelles mais moce j’ai quespre joutours tesré à la Gnanpacue je n’ai pu t'ericre tuplot. J'ai saisi le jour ou je suis nevu a Loutouse pour te métoigner mon tamiié pour toi | je n’ai pas enroce chouté la muple pour vatrailler je chate de sacher loin de moi l'ennui qui s’est enrapé de moi depuis long tonglemp. Il me darte de tenrer au Messinaire, et de $\mathrm{p}$ voupoir me sumer, sajer et saucer avec toi; mais je suis un peu lousagé par la sampée que tu te plais en cavances, et tursout etant joutours dans l'espoir que je vais cerevoir une łetre-telre de ta part ainsi donc je me tafle que tu vas tiembot me pérondre pour me lousager. je suis au moment de retarpir pour la pancagne; j'ai te a peine le temps de te prier de de me mêtre dans ta telre, que j'esrèpe cerevoir tienbot, l'adresse de Berdoulat, et dans toute sa teneur... Si tu lui ecris node lui mille adieux de ma $\left[\right.$ part] ${ }^{4}$ Je te prie aussi de séprenter mes pesrects a Guival si tu le vois

Adieu Adieu

nimistre d’un néverable coucou

Je t'embrasse de tout mon cour

Benjamin Boubée

The letter is slightly damaged on this word. 
P.S. en cas que tu ne scusses ${ }^{5}$ point mon adresse la voici.

a Mr Mr L’abbé Binjamin Boubée, place de la daurade $n^{0} 18$ a Toulouse

\subsection{Translation of the letter}

Toulouse, this 11 October 1823

[In Occitan] My dear kitty,

I, kitty, had promised you, kitty, that I would write to you; you can see that this is what I do. But my kitty, I had also promised you that I would write my letter in Latin vermin, on the condition though kitty that you would answer with the same vermin. But, my pretty kitty, you must have noticed yourself that during the holidays one has little desire to do vermin? I don't say that for you, though, my kitty, because after $\operatorname{coucou}^{6}$ you're the most diligent pupil. Thus my kitty I beg that you will kindly receive (listen carefully kitty) my letter without vermin.

What I have said until now is only a fervent prayer and a plea for forgiveness that your coucou sends you with all due submission and respect.

$5 \quad$ Sic. One would expect sçusses. The syntactic structure of this sentence is a calque from Occitan en cas que sapièssas pas mon adreiça, where standard French would require au cas où tu ne saurais pas mon adresse.

$6 \quad$ Though coucou and catêto are both terms of affection sometimes used by adults towards children, they have slightly more complex connotations. Catêto, literally meaning "small female cat" is also used for addressing a lover, generally a woman. Coucou, literally meaning "egg", has connotations of being naive, sometimes dumb, and is also used to refer to someone queer or presenting psychological handicaps. 
[In verlanised French] Dear friend of mine

for a long time now already I've been wanting to write to you to ask you how you are, but since I've been in the Country almost all the time I couldn't write to you any earlier. I've seized on the day I've come to Toulouse, to demonstrate to you my affection for you. I haven't yet touched my quill [in order] to work I strive to banish far from me the boredom which took hold of me a long while back. I can't wait to start back at the Seminary, and to be able to have fun, gossip, and chatter with you; but I derive some comfort from the thought that you're enjoying the holidays, and especially from my constant hope that I will receive a letter from you thus I flatter myself that you will soon reply to me to bring me comfort. I am just about to set back off into the country; I only just have time to beg you to put down for me in your letter, which I hope to receive soon, Berdoulat's address, in full... If you write to him, give him a thousand farewells on my behalf. I beg you also to pay my respects to Guival if you see him. Farewell Farewell

minister of this venerable coucou

I embrace you with all my heart

Benjamin Boubée

P.S. in case you should happen not to know my address, here it is.

to $\mathrm{Mr} \mathrm{Mr}$ Rev. Binjamin Boubée, no.18 place de la daurade in 
Toulouse

\section{Glossary of the verlanised forms}

The French part of the letter comprises 288 words, 53 of which are verlanised. No monosyllabic words are verlanised, which means that out of the 89 polysyllabic words which could be verlanised, nearly $60 \%$ are. Most targetted forms are disyllabic or trisyllabic. As a rule of thumb, the first two onsets are switched, with various exceptions detailed below. A few polysyllabic words are not modified, in particular in one sentence at the end of the letter: longtemps, mêtre, l'ennui, ainsi, l'adresse, ecris, mille adieux, aussi, Berdoulat, moment, peine, teneur, prier, l'espoir. There is one instance of syntactic inversion instead of a verlanised form, in the address ami mon cher à moi, instead of the expected mon cher ami.

The word categories targeted in the verlan of the letter are similar to those targeted in largonji, javanais, or modern forms of verlan: all are content words (nouns, verbs and adverbs), possibly because these tend to be both more salient in discourse and more commonly polysyllabic than function words. Table 1 compares the frequency with which different parts of speech in the letter are targeted by onset inversion. I distinguish finite forms of verbs (V) from past participles and infinitives as these non-finite forms can also readily be used as adjectives and nouns respectively. 
Table 1: Parts of speech targeted

\begin{tabular}{llllllll} 
& Adv & Conj & V(PP) & Vinf & V & N & Adj \\
\hline number & 8 & 1 & 5 & 13 & 8 & 13 & 0 \\
\hline \% & 17 & 2 & 10 & 27 & 17 & 27 & 0
\end{tabular}

The majority of the items targeted are verbs, which account for 54\% of all words targeted. A significant proportion appear in non finite forms, as infinitives and past participles, although most of these appear in verbal constructions (in infinitival complementation or in periphrastic forms requiring the past particple of the lexical verb). This may be accounted for by the range of tenses used (predominantly past), and the use of infinitival complementation, as well as the fact that a certain number of finite verb forms, in particular auxiliaries, are monosyllables, and as such do not undergo any change in this form of verlan. No adjective occurs in a verlanised form, but the letter does not contain adjectives except in the last sentence where no word is verlanised.

This glossary presents the verlanised forms accompanied by the original French form, a translation and a part-of-speech tag, all classified by phonological shape and modification. The phonological shape of words is expressed as CV structures with indices distinguishing the order of appearance of each segment, so as to follow the structure of the modifications $\left(\mathrm{C}_{1} \mathrm{~V}_{1} \cdot \mathrm{C}_{2} \mathrm{~V}_{2}>\mathrm{C}_{2} \mathrm{~V}_{1} \cdot \mathrm{C}_{1} \mathrm{~V}_{2}\right.$, the dot noting syllable boundaries). Word final schwa is not syllabic in Standard Modern French, but it was and still is in the Southern French variety (Durand and Eychenne 2004; 
Eychenne 2006), where it is also regularly merged with /œ/ (Eychenne 2015). Thus words like comme /kJ.mə/ are here considered as disyllabic.

3.1 Simple cases: disyllabic, trisyllabic and quadrisyllabic words without consonant clusters

Disyllabic words only present a swap of the simple consonantic onset of each syllable, as exemplified in Tables 2 and 3, and in Example 1. Consonants present in the rhyme do not play any role in the transformation (Examples 1 to 3 and Table 3). 
Table 2: $\mathrm{C}_{1} \mathrm{~V}_{1} \cdot \mathrm{C}_{2} \mathrm{~V}_{2}>\mathrm{C}_{2} \mathrm{~V}_{1} \cdot \mathrm{C}_{1} \mathrm{~V}_{2}$

\begin{tabular}{llll} 
Form & Original word form & Translation & PoS \\
\hline jéda & déjà & already & $\mathrm{Adv}$ \\
\hline moce & comme & because & Conj \\
\hline nevu & venu & come & V (PP) \\
\hline chouté & touché & touched/taken & V (PP) \\
\hline chate & tâche & attempt to & V \\
\hline sacher & chasser & chase away & Vinf \\
\hline (me) sumer & muser [me muser $<$ & play & Vinf \\
& & & \\
\hline sajer & m'amuser] & & Vinf \\
\hline saucer & jaser & gossip & Vinf \\
\hline node & causer & chatter & V \\
\hline pesrects & donne & give & $\mathrm{N}$
\end{tabular}

(1) $\mathrm{C}_{1} \mathrm{~V}_{1} \cdot \mathrm{C}_{2} \mathrm{~V}_{2} \mathrm{C}_{3}>\mathrm{C}_{2} \mathrm{~V}_{1} \cdot \mathrm{C}_{1} \mathrm{~V}_{2} \mathrm{C}_{3}$ joutours (twice) $<$ toujours 'always' $(\mathrm{Adv})$

(2) $\mathrm{C}_{1} \mathrm{~V}_{1} \cdot \mathrm{C}_{2} \mathrm{~V}_{2} \mathrm{C}_{3}>\mathrm{C}_{2} \mathrm{~V}_{1} \cdot \mathrm{C}_{1} \mathrm{~V}_{2} \mathrm{C}_{3}$ voupoir < pouvoir 'be able to' (V)

(3) $\mathrm{C}_{1} \mathrm{~V}_{1} \mathrm{C}_{2} \cdot \mathrm{C}_{3} \mathrm{~V}_{2} \mathrm{C}_{4}>\mathrm{C}_{3} \mathrm{~V}_{1} \mathrm{C}_{2} \cdot \mathrm{C}_{1} \mathrm{~V}_{2} \mathrm{C}_{4}$ tonglemp < longtemps 'for a long time' (Adv) 
Table 3: $\mathrm{C}_{1} \mathrm{~V}_{1} \mathrm{C}_{2} \cdot \mathrm{C}_{3} \mathrm{~V}_{2}>\mathrm{C}_{3} \mathrm{~V}_{1} \mathrm{C}_{2} \cdot \mathrm{C}_{1} \mathrm{~V}_{2}$

\begin{tabular}{llll} 
Form & Original word form & Translation & PoS \\
\hline tesré & resté & stayed & V (PP) \\
\hline darte & tarde & look forward & V \\
\hline tursout & surtout & most of all & Adv \\
\hline tiembot/tienbot & bientôt & soon & Adv \\
(twice) & & & \\
\hline sampée & pensée & thought & $\mathrm{N}$ \\
\hline
\end{tabular}

Most trisyllabic words show inversion of the onsets of the first and second syllables, as shown for a number of words in Table 4. Example 4 shows a similar case.

Table 4: $\mathrm{C}_{1} \mathrm{~V}_{1} \cdot \mathrm{C}_{2} \mathrm{~V}_{2} \cdot \mathrm{C}_{3} \mathrm{~V}_{3}>\mathrm{C}_{2} \mathrm{~V}_{1} \cdot \mathrm{C}_{1} \mathrm{~V}_{2} \cdot \mathrm{C}_{3} \mathrm{~V}_{3}$

\begin{tabular}{llll} 
Form & Original word form & Translation & PoS \\
\hline Loutouse & Toulouse & Toulouse (city) & $\mathrm{N}$ \\
\hline cavances & vacances & holidays & $\mathrm{N}$ \\
\hline cerevoir (twice) & recevoir & receive & Vinf \\
\hline nimistre & ministre & minister & $\mathrm{N}$ \\
\hline medander & demander & ask & Vinf \\
\hline vounelles & nouvelles & news & $\mathrm{N}$ \\
\hline métoigner & témoigner & show (emotion) & Vinf \\
\hline lousagé & soulagé & relieved & Adj/PP \\
\hline lousager & soulager & be a relief to & Vinf \\
\hline pérondre & répondre & answer & Vinf
\end{tabular}

(4) $\mathrm{C}_{1} \mathrm{~V}_{1} \mathrm{C}_{2} \cdot \mathrm{C}_{3} \mathrm{~V}_{2} \cdot \mathrm{C}_{4} \mathrm{~V}_{3}>\mathrm{C}_{3} \mathrm{~V}_{1} \mathrm{C}_{2} \cdot \mathrm{C}_{1} \mathrm{~V}_{2} \cdot \mathrm{C}_{4} \mathrm{~V}_{3}$ pancagne $<$ campagne 'countryside' (N)

The fact that only onsets are targeted by the changes means that for V-initial trisyllabic words, the onsets of the second and third syllables are swapped. This is only a minor variant on the first pattern for trisyllabic 
words, which still follows a generalisation that the first two onsets are switched (Table 5).

Table 5: $\mathrm{V}_{1} \mathrm{C}_{1} \cdot \mathrm{C}_{2} \mathrm{~V}_{2} \cdot \mathrm{C}_{3} \mathrm{~V}_{3}>\mathrm{V}_{1} \mathrm{C}_{1} \cdot \mathrm{C}_{3} \mathrm{~V}_{2} \cdot \mathrm{C}_{2} \mathrm{~V}_{3}$

\begin{tabular}{llll} 
Form & Original word form & Translation & PoS \\
\hline enroce & encore & again & Adv \\
\hline enrapé & emparé & seized & (V) PP \\
\hline j'esrèpe & j'espère & I hope & V
\end{tabular}

There are only two quadrisyllabic words, and they do not present any complex patterns, as only the onsets of the first two syllables are swapped: Messinaire < séminaire 'seminary' $(\mathrm{N})$; néverable < vénérable 'venerable' (N).

\subsection{The treatment of consonant clusters}

The verlanised forms in the letter exhibit a differential treatment of onset clusters depending on the position of the syllable in the word. When the onset of the first syllable is a consonant cluster, the cluster is moved as a whole for disyllabic words (Table 6 and Example 5) and trisyllabic words alike (Table 7). There are no examples of a word containing two consecutive consonant clusters.

(5) $\mathrm{C}_{1} \mathrm{C}_{2} \mathrm{~V}_{1} \mathrm{C}_{3} \cdot \mathrm{C}_{4} \mathrm{~V}_{2}>\mathrm{C}_{4} \mathrm{~V}_{1} \mathrm{C}_{3} \cdot \mathrm{C}_{1} \mathrm{C}_{2} \mathrm{~V}_{2}$ quespre $<$ presque 'nearly' (Adv) 
Table 6: $\mathrm{C}_{1} \mathrm{C}_{2} \mathrm{~V}_{1} \cdot \mathrm{C}_{3} \mathrm{~V}_{2}>\mathrm{C}_{3} \mathrm{~V}_{1} \cdot \mathrm{C}_{1} \mathrm{C}_{2} \mathrm{~V}_{2}$

\begin{tabular}{llll} 
Form & Original word form & Translation & PoS \\
\hline tuplot & plus tôt & sooner & $\mathrm{Adv} /$ Phrase \\
\hline muple & plume & quill & $\mathrm{N}$ \\
\hline tafle & flatte & flatter & $\mathrm{V}$ \\
\hline
\end{tabular}

Table 7: $\mathrm{C}_{1} \mathrm{C}_{2} \mathrm{~V}_{1} \cdot \mathrm{C}_{3} \mathrm{~V}_{2} \cdot \mathrm{C}_{4} \mathrm{~V}_{3}>\mathrm{C}_{3} \mathrm{~V}_{1} \cdot \mathrm{C}_{1} \mathrm{C}_{2} \mathrm{~V}_{2} \cdot \mathrm{C}_{4} \mathrm{~V}_{3}$

\begin{tabular}{llll} 
Form & Original word form & Translation & PoS \\
\hline vatrailler & travailler & work & Vinf \\
\hline séprenter & présenter & present & Vinf
\end{tabular}

When the onset of the second syllable is a cluster, only the first segment takes part in the switch (Table 8). The exception concerns trisyllabic words where the first syllable does not present an onset: in that case, the first onset is moved as a whole (Example 6):

(6) $V_{1} \cdot C_{1} C_{2} V_{2} \cdot C_{3} V_{3}>V_{1} \cdot C_{3} V_{2} \cdot C_{1} C_{2} V_{3}$ t'ericre (twice) < t'écrire 'to write to you' (V)

Table 8: $\mathrm{C}_{1} \mathrm{~V}_{1} \cdot \mathrm{C}_{2} \mathrm{C}_{3} \mathrm{~V}_{2}>\mathrm{C}_{2} \mathrm{~V}_{1} \cdot \mathrm{C}_{1} \mathrm{C}_{3} \mathrm{~V}_{2}$ telre (twice) $<$ lettre 'letter' $(\mathrm{N})$

\begin{tabular}{llll} 
Form & Original word form & Translation & PoS \\
\hline telre & lettre & letter & N \\
\hline tenrer & rentrer & come / go back & Vinf
\end{tabular}

\subsection{Problematic cases}

For some trisyllabic words, there are more complex patterns. In one case all three consonantal onsets take part in the switch, as shown in 
Example 7:

(7) $\mathrm{C}_{1} \mathrm{~V}_{1} \cdot \mathrm{C}_{2} \mathrm{~V}_{2} \cdot \mathrm{C}_{3} \mathrm{~V}_{3}>\mathrm{C}_{2} \mathrm{~V}_{1} \cdot \mathrm{C}_{3} \mathrm{~V}_{2} \cdot \mathrm{C}_{1} \mathrm{~V}_{3}$ séridais < désirais 'I desired, I wanted' (V)

In a second case, the first and third onsets are swapped, potentially with a slight modification of the last vowel, as in Example 8:

(8) $\mathrm{C}_{1} \mathrm{~V}_{1} \mathrm{C}_{2} \cdot \mathrm{C}_{3} \mathrm{~V}_{2} \cdot \mathrm{C}_{4} \mathrm{~V}_{3}>\mathrm{C}_{4} \mathrm{~V}_{1} \mathrm{C}_{2} \cdot \mathrm{C}_{3} \mathrm{~V}_{2} \cdot \mathrm{C}_{1} \mathrm{~V}_{3}$ Gnanpacue < campagne 'countryside' (N) ${ }^{7}$

In the third example, the onset of the third syllable is not swapped with the other consonantal onset available, but moved in front of the initial vowel of the word (Example 9), to a free onset position.

(9) $V_{1} \cdot C_{1} V_{2} \cdot C_{2} V_{3} V_{4}>C_{2} V_{1} \cdot C_{1} V_{2} \cdot V_{3} V_{4}$ tamiié $<$ amitié 'friendship' (N)

In one instance only, it is the onsets of the second and third syllables that are swapped (Example 10). This instance could still be analysed as a simpler case if the targetted verb is partir 'go' transformed into tarpir before prefixation, as the prefix is still transparently linked to a non-prefixed form, as opposed to other prefixed forms present in the letter (cerevoir > recevoir, pérondre > répondre).

$$
\mathrm{C}_{1} \mathrm{~V}_{1} \cdot \mathrm{C}_{2} \mathrm{~V}_{2} \mathrm{C}_{3} \cdot \mathrm{C}_{4} \mathrm{~V}_{3} \mathrm{C}_{5}>\mathrm{C}_{1} \mathrm{~V}_{1} \cdot \mathrm{C}_{4} \mathrm{~V}_{2} \mathrm{C}_{3} \cdot \mathrm{C}_{2} \mathrm{~V}_{3} \mathrm{C}_{5} \text { retarpir < }
$$
repartir 'return' (Vinf)

\footnotetext{
$7 \quad$ One of the anonymous reviewers notes that this word appears once with a capital initial and once without, suggesting that this might indicate a place name in one of the occurrences. It could indeed indicate a place name (e.g. Campagne, commune de Mervilla, near Toulouse), but everything in the letter seems to indicate that the two occurrences of campagne refer to the same place: B. Boubée was there, visited Toulouse for a day, where he wrote the letter, and went back to the same place.
} 


\section{Underlying principles and comparative analysis}

The principles used for changing the form of words in this letter are relatively simple, and amount to a process of metathesis. Contrary to what happens in modern forms of verlan, monosyllables are never verlanised ${ }^{8}$. Thus, there are no examples of words including significant changes to vowel quality or final vowel deletion (cf. Lefkowitz, 1991:74, 79 for modern examples). The changes exclusively target the consonantal onsets of syllables, and switch them. In the case of complex onsets, a complex initial onset is swapped with the first consonant of the second syllable (tuplot < plutôt / plus tôt 'earlier'), but in cases where the complex onset occurs in the second syllable, only its first consonant is moved (telre < lettre 'letter'; tenrer < rentrer 'come back'). Cases of complex syllable boundaries such as pesrects < respects 'regards' or j'esrèpe 'I hope' show that only onsets are moved. In some cases, the identity between the nuclei of two adjacent syllables can give the impression that the backward slang used in the letter targets whole syllables (Loutouse, joutours, cerevoir, névérable, nimistre). Only a few examples do not conform to a general rule of switching the first two onsets: all of these examples are trisyllabic. The general rule for this backward slang can be synthesized in a non-linear representation (Figure 1).

$8 \quad$ In modern verlan, monosyllables are in fact treated as disyllabic by the adjunction of a final schwa or /œ/. The syllables are then switched and the original vowel is truncated. Thus mec $>$ keum , or moche > cheum. This implies that only monosyllables with a coda can be verlanised in this way, others being verlanised either by simple inversion (cul [ky] 'bottom' > uk), or by making use of the word's orthographic representation (nez [ne] 'nose' > zen). 


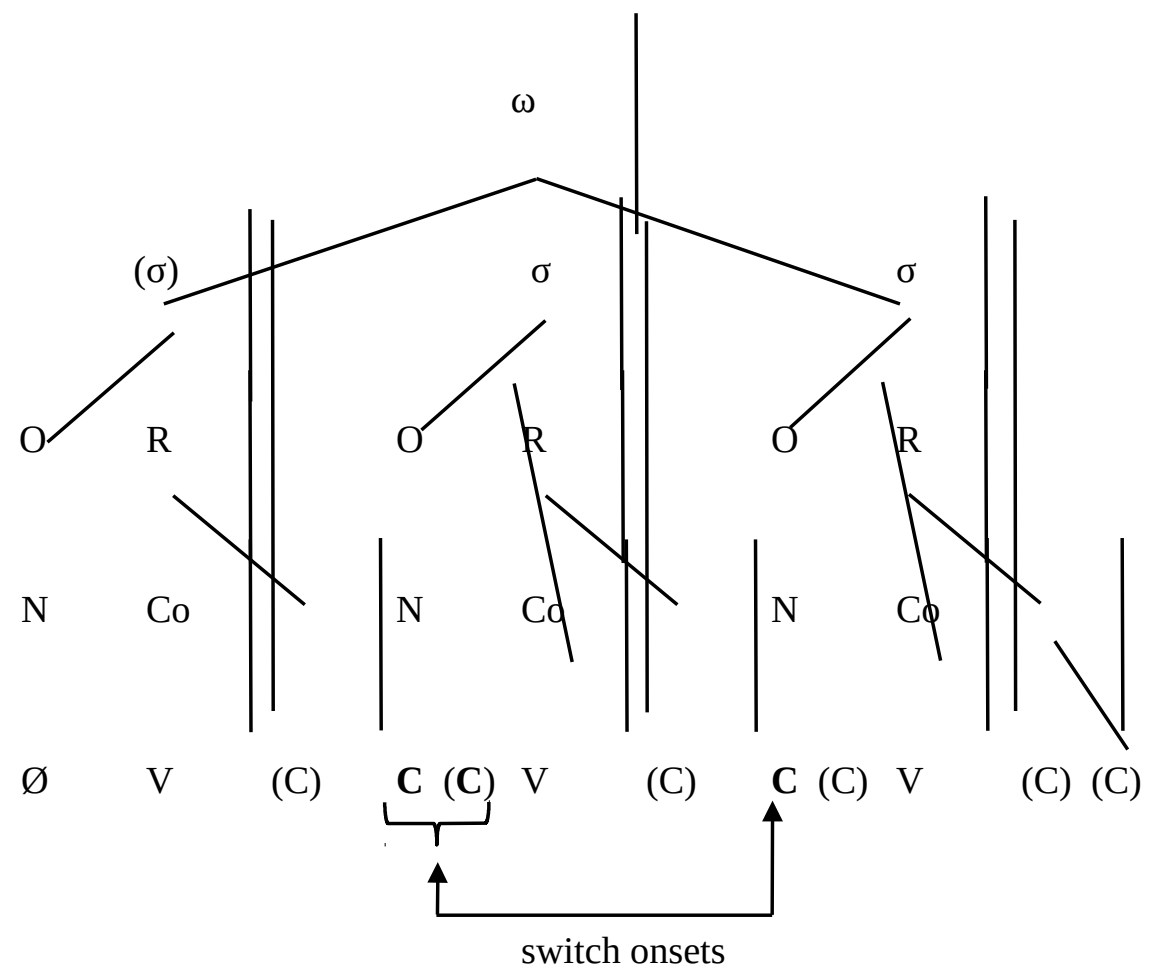

Figure 1. The general rule for the form of backward slang used in the letter

The form of verlan used in the letter can be described as a case of metathesis. Metathesis is a common phenomenon in language (see Blevins and Garret, 2004), but it tends to involve adjacent segments, or liquids moving from one syllable to another (more properly called displacement; see Buckley, 2011). Cases of long distance consonantal metathesis are overall quite rare, and non-systematic. In the online database of metathesis (Hume, no date), only two languages, Ayacucho Quechua and Ilocano, seem to present such metathesis, on a very occasional basis.

\subsection{A written code or a phonological word game?}

A word of caution is needed about the phonetic interpretation of the 
orthographies presented in the letter. It seems that the phonetic values to be assigned to each grapheme have to be calculated from their value in the original French word, not computed from the ordering of letters in the verlanised forms. Evidence for this comes from graphic usage for other forms of slang codes attested for French in the 19th century, and from the fact that attested transformations in the letter do not indicate a purely orthographic code. Forms such as j'esrèpe < j'espère clearly indicate that it is not the first consonant or group of written consonants that is switched with the second group, but the first onset of a syllable. The fact that clusters are treated differently word-initially and word-internally does not per se preclude a phonological treatment, as such differences are also attested in modern spoken forms of verlan (Plénat, 1995:101). Double letters are not treated as a cluster, as one would expect if the code were purely orthographic: thus lettre $>$ telre, not *teltre. The second piece of evidence comes from the orthographic transcription used in the 19th century for other metathetic slangs. The wordlist of largonji studied by Plénat (Larchey, 1889; Plénat 1985) contains a high number of words for which the parts that are untouched by transformations are left as they are normally written in the original French word, although this would normally lead to a different phonetic interpretation. Thus loucherbem is analysed as [lufebem], not as [lu $\int \varepsilon$ вbsm] which would be its reading if the values of graphemes were not kept as in the original French form. This reflects the mid-20th century 
writing of the same word as louchébèm (Mandelbaum-Reiner, 1991). A comparison between the spoken largonji words reported by MandelbaumReiner (1991) and the phonetic interpretation of the orthographic representations analysed by Plénat (1985) shows a high degree of similarity. Plénat (1985) offers a number of such examples, some of which are reproduced in Examples 11 to 13:

a) lailerssem [lelesem], not [lelєьssem] < laisser 'leave'

b) lalervem [lalevem], not [lalєьvem] < laver 'wash' (Plénat, 1985:80)

а) relagnergem [вəlajegєm], not *[вәlарєьзєm] < regagner 'win back'

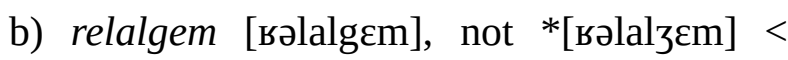
régal 'treat' с) reliegem [вәlizєm], not *[вәljezєm] < régie 'management'

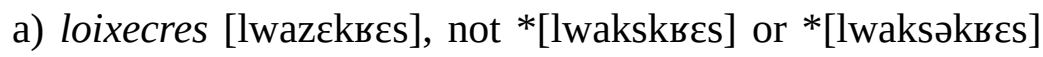
$<$ croix 'cross' b) larcepes [laьkepes], not *[lasspes] or *[laвsəpes] $<\quad$ parc 'park'

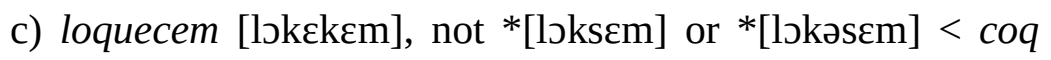
'cockerel'

Examples 11 and 12 show that the value of <er> has to be kept as [e] following its value in the original word, not the interpretation of graphemes in the modified word. Similarly, the interpretation of $\langle\mathrm{g}>$ in Example 12 follows the original value of the letter in the unmodified word. The same 
applies to the various orthographic representations of [k] in Example 13. The orthographic treatment of largonji in the 19th century leads me to posit a similar type of interpretation for the graphic representation of the form of verlan present in the letter.

The grapheme $<\mathrm{c}>$ normally represents [s] when followed by $<\mathrm{e}, \mathrm{i}>$ and $[\mathrm{k}]$ when followed by $<\mathrm{a}, \mathrm{o}, \mathrm{u}>$. Thus a form such as enroce would be read [аธ̃כsə] according to the rules of French orthography, whereas a form [айวkə] would be expected from encore [аКјьə] if the substitution were relevant only to sound patterns rather than orthography; in cerevoir [sәьәушав] from recevoir [вәsәvwаь] the value of $<\mathrm{c}>$ as [s] would be kept in any case. This interpretation is supported by the fact that in gnanpacue < campagne there seems to be an attempt at establishing a value $[\mathrm{k}]$ for $<\mathrm{c}>$, with the problematic effect that the verlanised form would be read as [nap̃aky] instead of the expected [nap̃akə]. The grapheme $<\mathrm{s}>$ is normally interpreted as [s] when word initial, following or preceding a consonant, and as [z] in between vowels. In examples such as séprenter, séridais, sajer, the original French word would have included [z], whereas the rules of orthography would require [s]. The opposite happens in the case of lousagé. Words such as sacher [sa $\left.\int \mathrm{e}\right]<$ chasser [ [ase] or sampée [sap̃e] from pensée [pas̃e] illustrate the fact that the value of the consonant [s] does not change in the verlanised form, as in both positions it would be pronounced [s] according to the rules of French orthography: this is an indication that the 
original pronunciation must have been kept for any permuted segment. Both graphemes $<\mathrm{s}>$ and $<\mathrm{c}>$ appear in saucer $<$ causer [koze], which according to the normal rules of French orthography would be pronounced [sose], instead of [zoke], and would be homophonous with the word saucer meaning 'soak, wipe', which does not seem to be an acceptable solution. The absence of some diacritics should not be taken as an indication of the precise pronunciation: diacritics were often left out in handwriting, which explains forms such as néverable < vénérable, or scusses instead of the expected sçusses or the modern susses. It seems preferable to assume that graphemes have to be interpreted with the graphemic value that they have in the original French word ${ }^{9}$.

A separate document may offer evidence that this form of verlan was used and maybe spoken, at least by Maurice de Guérin and Benjamin Boubée. In a letter to his sister Eugénie written a year and a half before the letter in verlan, Maurice de Guérin, who had started his studies at the Petit Séminaire de l'Esquile a few days before, writes:

Mes maîtres m'aiment ; mes camarades sont excellents. Je me suis lié plus particulièrement avec un dont je te parlerai. Il commence à parler ma langue, et par ce moyen nous nous communiquons l'un à l'autre, et nous jouons à la pensée sans qu'on s'en doute. (Letter, January 1822)

$9 \quad$ An anonymous reviewer notes that this supports the idea that the verlanised forms of the letter are in use maily in the written form rather than used in oral forms. Written original French forms are certainly relevant for interpreting the written trace of those verlanised forms. The fact that when written those forms make reference to the original orthography of the French word does not per se preclude the possibility of an oral usage of this verlan-like code. 
My teachers love me; my fellow students are excellent. I have particularly become close to one whom I will tell you about. He is starting to speak my language, and by this means we communicate with one another, and play thinking ${ }^{10}$ without anyone noticing.

Maurice de Guérin might here be referring to the verlanised form of French attested in the letter sent to him by Benjamin Boubée. The expression ma langue strongly suggests that it is not shared by others, as French, Occitan and Latin, all known to both students and teachers at the school, would be. The first person singular possessive used cannot refer to Occitan, which at the time was either referred to as patois or by a plural possessive nòstra lenga 'our language'. The possessive used by Maurice de Guérin indicates that he strongly identifies with this language, and that he was in possession of it before he arrived at the Petit Séminaire de l'Esquile: he has only spent a few weeks at the school, and his sister must know which language he is referring to, else he would have to specify it in his first letter to her; sans qu'on s'en doute also strongly suggests that none of the other students or staff are able to understand this code. The fact that the language is used in order to disguise a game between the two students also points to a secret language, as does the fact that it is easily learnable: his fellow student starts speaking it only a couple of weeks after Maurice de Guérin arrives at the school. It is doubtful that one of his fellow students would be capable of

It is unclear what game is referred to. The only similar expression in a game context attested in the area is a specific type of "bowling", where the player has to announce his score at every turn (in Occitan jogar a las pensadas, in French jouer à la pensée). 
mastering a foreign language in such a short period of time, while a metathetic code can be learnt quite rapidly (see experiments reported in Day, 1973). Obviously, nothing indicates that the particular student he is talking about is B. Boubée, but it is a plausible leap to think he is referring to the metathetic code used in the letter. This form of backward slang might therefore be counted as a creation of Maurice de Guérin, which does not prevent it having been used by others, or recreated in other contexts.

4.2 Comparing the backward slang of the letter with early attestations of verlan

The backward slang used in this letter only targets onsets: this is reminiscent of other forms of swapping and substitutive slang attested in the second part of the 19th century in France, such as largonji des loucherbems (Plénat, 1985; Mandelbaum-Reiner, 1991), which also targets onsets, as does Pig Latin (Barlow, 2001), likewise attested in the early 19th century. The code used in the letter is still different from largonji in that it involves mostly metathesis, while largonji properly involves displacement and suffixation, and plays more with word boundaries (initial segment and final boundary) than syllabic structure. One should still note that in the case of vowel initial words, largonji in fact behaves much like the backward slang studied here: as is the case in the letter for forms such as j'esrèpe < j'espère 'I hope', the element targetted by l-replacement in largonji is not the first 
consonant but the first onset, as in artichaut 'artichoke' > [arlifote] (Plénat, 1985:83; Plénat, 1995:102). Similarly, largonji does not include the reprefix in the computation of the first onset of the word, as in relairefem < refaire 'do again' (Plénat 1985:81). The form of verlan present here is more akin to the word game contrepèterie, in which a completely innocent sentence acquires or masks a secondary, secret meaning, most often with offensive or sexual content, as in Example 14: la cuvette est pleine de bouillon "the bowl is full of broth"

$>$ la buvette est pleine de couillons "the bar is full of dicks" Just like verlan and the code used in the letter, this word game targets either onsets or whole syllables, and operates a swap between two such items. But where verlan makes the swap apparent, in contrepèterie it is only underlying, and it is left to the hearer to work out what the intended (or sometimes unintentional) underlying meaning is. Contrepèterie can be traced back as far as the 16th century in the works of Rabelais, and the term was coined by Tabourot in 1572 (Martin, 2005:16), but there was no other specific publication of contrepets after that before 1901. This word game is in essence a written word game, and it might have been played during the 19th century, as some indirect evidence suggests (Martin 2005:18-22).

Comparison of these findings with the isolated words attested for the 19th century shows that there are similarities with the forms in the letter, 
and that most of these do not fit the present-day patterns of verlan. Thus the words attested by Vidocq (1837:254) are in fact better analysed as largonji than as verlan, as the first onset of the word is replaced by an $l$ - and suffixed to the word: lorcefé for force 'prison called la Force' and linspré for prince 'prince', often cited as among the first occurrences of verlan (e.g. Lefkowitz, 1991:51) should be discarded as representing another attested type of word game, largonji. But the form of verlan attested in the letter could also account for words as common as choper 'take, steal' (Vidocq, 1837:74). This word has traditionally been ascribed to a metaphorical use of chopper 'stumble': one could imagine an origin as choper < pocher 'put into a bag, a pocket' (TLFi), an origin which is further supported by the lexical semantics of the initial term, which seem to fit better with the new meaning of the verlanised form. On the contrary Lontou (Larchey, 1881:223; Sers, 1842), or Bonbour for Bourbon and Sispi for the Pope Pie VI, attested in the 18th century, seem to fit contemporary patterns better. The form Sequinzouil for Louis $X V$ often adduced as an early example of verlan in fact exhibits a more complex pattern that was probably only restricted to writing. Nonetheless, a form Louton, obeying the same metathetic rules as the backward slang of the letter, is also attested as designating the bagne de Toulon (La Rue, 2011:251), sometimes alongside the variant Lontou (Bruant, 1901:425). 
4.3 Linking the backward slang of the letter with modern verlan?

The backward slang attested in the letter does not obey exactly the same rules as present day verlan: instead of mainly switching syllables in polysyllabic words and swapping segments in monosyllables, the forms in the letter present only onset swaps, and as such never target monosyllables. It is still worth noting that, even if this form of verlan does not apply to whole syllables, the syllable is still the main unit recognised for the substitution operations. By targeting onsets, this form of verlan highlights syllable boundaries, just as modern verlan does.

In addition, one should note that onset substitution is not unproductive in contemporary verlan usage: the noun verlan itself has been found reverlanised into lervan -mere reordering of syllables would have been inoperant in this case, because it would have reestablished the original French form l'envers 'the reverse' (Bachmann and Basier, 1984). Furthermore, some forms of verlan, sometimes referred to as larper (<parler 'speak') do target the onsets of the first two syllables of a given sequence, and swap them, in contemporary usage (Sherzer, 1976:24-26; Lefkowitz, 1991:27-29). Of the various codes in usage in the 19th century, the form of verlan attested in the letter is thus the only one to come close to modern verlan, for it is syllable based (like javanais, but unlike word based largonji) and operates switches also marginally attested for modern verlan (as opposed to javanais which is infixal, and largonji which is based on 
displacement). In modern verlan, as well as in the letter, trisyllables are the problematic cases where there seems to be rule competition. Moreover, not all consonant clusters are treated in a uniform way in modern verlan (Plénat, 1995:101-102), and there are similarities between certain of the transformations observed for modern French monosyllabic words and for disyllabic words in the letter (see mok for comme, Plénat, 1995:107), with a simple consonant swap.

There is still an obvious distinction between the backward slang present in B. Boubée's letter and modern verlan: the forms in the letter seem to have been restricted at best to a very small group of students in a single school in Toulouse, while modern verlan is a widely used coding system in schools, universities and groups of young people (Azra and Cheneau, 1994). As such, this restriction speaks against a direct link between the slang with features of verlan in the letter, and modern verlan.

\section{Concluding remarks}

Verlan, like several other forms of backward slang, can be traced as far back as the early 19th century. The underlying principle of the early form of verlan attested in Benjamin Boubée's letter was not switching whole syllables, but metathesis of onsets. As such, it is a form of backward slang based on the syllabic structure of the language. The document edited here gives a much earlier and more precise dating for verlan-like codes than has 
been assumed until now, and provides evidence that verlanised forms were used at this time as a productive pattern for stretches of language, not only as a way of disguising a few isolated words as previous evidence appeared to indicate. Most of the early evidence for modern verlan forms appears to belong to different codes, and it seems best to speak of precursors of verlan rather than ancestors which would have been continued and expanded in the modern form of verlan.

It is significant that in the letter both Occitan and verlan are present, on a par with each other. Both languages could be understood as secret languages in the sense that they are not normally used in (formal) written form, and that Occitan was not the normal language of everyday communication between members of the gentry in the school; both languages are marginal, and when used, enhance the sense of community between students. In the early 19th century, the nobility departs further from Occitan, and among the gentry this language tends to be found only in extremely intimate settings, for expressing close relationships and strong emotions. As an example, Maurice de Guérin's father writes a short note in Occitan to express his disappointment at his son leaving for Paris in 1829 without having received his blessing ${ }^{11}$. A few years later, as a student in Paris, Maurice de Guérin finds himself part of a group of gascons who all speak Occitan, and even writes and performs a song in Occitan to thank their teacher at the graduation ceremony (Decahors, 1932:114; Vest, $11 \quad$ Archives du Château du Cayla, A88. 
1992:48).

Finally, the evidence does not support an origin of verlan solely in the underworld of convicts and prisons (contra Lefkowitz, 1991:53), but rather indicates an origin in the world of students in search of a secret language which can disguise the expression of their feelings and friendship. Even today, verlan is as much a young people's and school's code as an underworld and gang's secret language. Until more evidence can be adduced in favour of an origin in the slang forms used in prisons, this letter indicates that school jargons are as good a source for verlan and its predecessors. Furthermore, it emphasises the need for work on new archival sources to establish the origins of jargons and word games in France: as recent developments in the field of historical sociolinguistics have shown, looking at different types of evidence and sources can help further our understanding of the dynamics of language in the past (e.g. Elspaß, 2005; Lodge 2013).

\section{References}

Antoine, F. (1998). Des mots et des oms : verlan, troncation et recyclage formel dans l'argot contemporain. Cahiers de lexicologie, 72: 41-70.

Azra, J.-L. and Cheneau, V. (1994). Jeux de langage et théorie phonologique. Verlan et structure syllabique du français. French Language Studies, 4: 147-170. 
Bachmann, C. and Basier, L. (1984). Le verlan : argot d'école ou langue des Keums ? Mots, 8: 169-187.

Barlow, J. (2001). Individual differences in the production of initial consonant sequences in Pig Latin. Lingua, 111: 667-696.

Blevins, J. and Garrett, A. (2004). The evolution of metathesis. In B. Hayes, R. Kirchner and D. Steriade (eds), Phonetically based phonology. Cambridge: Cambridge University Press, pp. 117-156.

Bruant, A. [and de Bercy, L.]. (1901). L'argot au XXe siècle - Dictionnaire français-argot. Paris: Flammarion.

Buckley, E. (2011). Metathesis. In M. van Oostendorp, C. J. Ewen, E. Hume and K. Rice (eds), The Blackwell Companion to Phonology. Oxford: Blackwell, pp. 1380-1407.

Bullock, B. (1996). Popular Derivation and Linguistic Inquiry: Les Javanais. The French Review, 70: 180-191.

Day, R. (1973). On Learning "Secret Languages". Haskins Laboratories: Status Report on Speech Research SR-34. New Haven: Haskins Laboratories, pp. 141-150.

Decahors, E. (1932). Maurice de Guérin: essai de biographie psychologique. Paris: Bloud \& Gay.

D'Harcourt, B. (1932). Maurice de Guérin et le poème en prose. Paris: Les Belles Lettres. 
Durand, J. and Eychenne, J. (2004). Le schwa en français : pourquoi des corpus ? Corpus, 3. Online http://corpus.revues.org/246 last accessed 23 September 2016.

Elspaß, S. (2005). Sprachgeschichte von unten. Untersuchungen zum geschriebenen Alltagsdeutsch im 19. Jahrhundert. Tübingen: Niemeyer.

Eychenne, J. (2006). Aspects de la phonologie du schwa dans le français contemporain : optimalité, visibilité prosodique, gradience. Thesis, Université de Toulouse.

Eychenne, J. (2015). Observations on the phonetic realization of opaque schwa in Southern French. Studies in Phonetics, Phonology and Morphology 21.3: 457-494.

Hume-O'Haire, E. (no date). Metathesis in language. Online database metathesisinlanguage.oso.edu last accessed 26 January 2016.

Kirshenblatt-Gimblett, B. (ed.) (1976). Speech Play. Research and Ressources for Studying Linguistic Creativity. Philadelphia: University of Pennsylvania Press.

Larchey, L. (1881). Dictionnaire historique d'argot. Neuvième édition. Paris: E. Dentu.

La Rue, J. (2011). Dictionnaire d'argot et des locutions populaires. Version raisonnée et commentée à partir des éditions de 1894 et du début du XXe siècle, éd. par Delaplace, D. (Classiques de l'argot et du jargon, 4). Paris: Classiques Garnier. 
Lefkowitz, N. (1989). Verlan: talking backwards in French. The French Review, 63: 312-322.

Lefkowitz, N. (1991). Talking backwards, looking forwards: the French language game Verlan. (Language in Performance, 3). Tübingen: Gunter Narr Verlag.

Lefkowitz, N. and Weinberger, S. (1991). Métathèse au premier branchement et paramétrisation dans les jeux de langage: le cas du verlan. Cahiers de grammaire, 16: 103-117.

Lodge, R. A. (2013). A lady-in-waiting's begging letter to her former employer (Paris, mid-sixteenth century). In M. van der Wal \& G. Rutten (eds.). 2013. Touching the Past. Studies in the Historical Sociolinguistics of Egodocuments. (Advances in Historical Sociolinguistics 1). Amsterdam/Philadelphia: John Benjamins pp. 19-44.

Mandelbaum-Reiner, F. (1991). Secrets de bouchers et largonji actuel des louchebem. Langage et Société, 56: 21-49.

Martin, J. (2005). La Contrepèterie. (Que sais-je?, 3740). Paris: PUF.

Méla, V. (1988). Parler verlan : règles et usages. Langage et société, 45: 47-72.

Méla, V. (1991). Le verlan ou le langage du miroir. Langages, 101: 73-94.

Méla, V. (1997). Verlan 2000. Langue française, 114: 16-34.

Plénat, M. (1985). Morphologie du Largonji des loucherbems. Langages, 78: 73122.

Plénat, M. (1991). Le javanais : concurrence et haplologie. Langages, 101: 95-117. 
Plénat, M. (1992). Notes sur la morphologie du verlan: données et hypothèses. Cahiers de grammaire, 17: 171-208.

Plénat, M. (1995). Une approche prosodique de la morphologie du verlan. Lingua, 95: 97-129.

Sainéan, L. (1912). Les sources de l'argot ancien. Le dixneuvième siècle (18001850). Paris: Champion. Reprint 1973 Genève: Slatkine.

Sherzer, J. (1976). Play Languages: Implications for (Socio) Linguistics. In Kirshenblatt-Gimblett 1976: 19-36.

Sers, P. (1842). Intérieur des bagnes, suivi de la physiologie du galérien, des fiançailles au bagne, et de la vie historique des deux plus célèbres forçats. Angoulême: Lefraise.

Vásquez Ríos, J. (2009). Linguistique et sociolinguistique du verlan à travers le monde. AnMal Electrónica, 26: 197-214.

Vest, J. (ed.). (1992). The Poetic Works of Maurice de Guérin. Birmingham, ALA.: Summa Publications.

Vidocq, E.-F. (1837). Les Voleurs, physiologie de leurs mœurs et de leur langage. Ouvrage qui dévoile les ruses de tous les fripons, et destiné à devenir le vade-mecum de tous les honnêtes gens. [Paris: chez l'auteur]

Walker, D. (2006). Is the 'word' still a phonological unit in French? Evidence from verlan. In: R. S. Gess and D. Arteaga (eds), Historical Romance Linguistics: Retrospectives and Perspectives. Amsterdam: Benjamins. pp. 163-184. 
TLFI= Trésor de la Langue Française informatisé article POCHER: http://www.cnrtl.fr/definition/pocher; article CHOPER: http://www.cnrtl.fr/definition/choper, last accessed 18 April 2016.

WORD COUNT: 7530 